\title{
Keeping it Clean: Cleaning Supplies ${ }^{1}$
}

Mary N. Harrison ${ }^{2}$

You do not have to buy expensive cleaning supplies. You can clean your home with common household ingredients.

\section{Equipment Needed for Cleaning}

- Rags, use soft material from worn-out clothing. Note: Remove buttons, zippers, and anything that will scratch.

- Measuring cup.

- Jars for mixing and/or storage. These may be containers that you saved such as mayonnaise or pickle jars. Do not use containers children associate with food.

- Broom.

- Vacuum cleaner (if you have carpets).

- Mop.

\section{Supplies}

- Liquid bleach

- Vinegar
- Baking Soda

- Liquid soap/detergent

- Ammonia

- Water

\section{Inexpensive Cleaners You Can Make}

\section{Sanitizing Solution}

Use for hard surfaces like cutting boards, counters, toys, doorknobs, cribs, trashcans, and mop heads.

- 3 Tablespoons Liquid Bleach

- 1 Tablespoon Liquid Soap, detergent

- 1 Gallon of Water

Wipe the surface and let stand for 2 minutes. Rinse and air dry.

1. This document is FCS5232-03, one of a series of the Family Youth and Community Sciences Department, Florida Cooperative Extension Service, Institute of Food and Agricultural Sciences, University of Florida. Original publication date June 2002. Revised December 2005. Visit the EDIS Web Site at http://edis.ifas.ufl.edu.

2. Mary N. Harrison, professor, Department of Family, Youth and Community Sciences, Cooperative Extension Service, Institute of Food and Agricultural Sciences, University of Florida, Gainesville, 32611.

The Institute of Food and Agricultural Sciences (IFAS) is an Equal Opportunity Institution authorized to provide research, educational information and other services only to individuals and institutions that function with non-discrimination with respect to race, creed, color, religion, age, disability, sex, sexual orientation, marital status, national origin, political opinions or affiliations. U.S. Department of Agriculture, Cooperative Extension Service, University of Florida, IFAS, Florida A. \& M. University Cooperative Extension Program, and Boards of County Commissioners Cooperating. Larry Arrington, Dean 


\section{Disinfecting Solution}

For cleaning toilet bowls, scrubbing grout in tile and tub areas, trashcans and other surfaces you need to disinfect.

- 3/4 Cup of Household Bleach

- 1 Teaspoon Liquid Soap

- 1 Gallon of Water

Wipe the surface and let stand for 2 minutes. Rinse and wipe or air dry.

\section{Everyday Household Cleaner}

- 2 Tablespoons Liquid Detergent/soap

- 2 Tablespoons Ammonia

- 1 Quart of Water

Use for all general cleaning jobs.

\section{Window Cleaner}

- 2 Tablespoons of Vinegar

-1 Quart of Water

Place contents in a large spray bottle for easier usage. Use crumpled up newspaper to shine the windows.

\section{Refrigerator Cleaner}

- 2 Tablespoons Baking Soda

- 1 Quart Warm Water

Wash the inside thoroughly using the above recipe (soap leaves an odor-do not use), including the shelves and drawers. Rub hard-to-clean spots with dry baking soda.

\section{Mildew Cleaner}

- 3/4 Cup Chlorine Bleach

- 1 Gallon Water

Mix and put in a spray container or apply with a brush. Apply to mildewed area, let stand for 5 minutes and rise with clear water.

\section{Remember}

Before you buy special cleaners try making you own. They work well, are safe to use and save you money. If you want to buy a cleaner, find one that does many jobs.

With all cleaning products remember:

- Its best to mix just what you need and use it all up.

- Be sure that the container has a label. If you make your own always label it.

- Never put cleaners in food containers.

- Store cleaning solutions where children cannot get them.

Never mix two or more cleaning products such as bleach, ammonia, toilet bowl cleaners, rust removers or oven cleaners. 